\title{
大潮差海域における幅広潜佂に用いる被覆ブロックの開発 Development of Armor Blocks to Use for Submerged Breakwaters in Large Tidal Zones
}

\author{
奥薗 英明* . 阿部 孝行 ${ }^{*}$, 矢島 昭弘 ${ }^{* *}$. 我原 弘昭 ${ }^{* *}$ \\ Hideaki Okuzono, Takayuki Abe, Akihiro Yajima and Hiroaki Gahara
}

\begin{abstract}
Submerged breakwaters are important coastal structures that protect seashore from waves. The transmission coefficient increases at high tide in large tidal zones. So, when the water depth is large over the submerged breakwater, effective armor blocks are developed. Eddies form between the ripple-type armor blocks during the onshore and offshore semiorbital wave motions. Incident waves reduce these eddies over the armor blocks, and trarismission coefficient becomes small.
\end{abstract}

Keywords; Submerged breakwater, Armor block, Transmission coefficient

\section{1.はしがき}

周囲を海に囲まれた我が国では、潜堤は高潮、波浪、侵食などの海岸災害防止に、また一般に海面下に位置 するので景観を損なうことがなく、安全な人エレクレーション空間の提供や、海水交換、魚礁効果など優れた 機能を発揮することにより高い評洒を得てきた ${ }^{1)}$ 。

しかし潮位変化の大きいところでは、満潮時に潜堤の天端上水深が大きくなり、十分な消波効果が得られな (2)、3)。そこで本研究では、大潮位時でも消波効果を発揮するような砂漣をイメージした新たな被覆ブロック を用いた潜堤を考案した。

砂漣は周知のように、波や流れによって海底にできる小さな波状形の起伏であるが4)、海底での流れの方向 が岸向きや沖向きに変化することにより、砂漣の凹部近傍では浮遊砂が水粒子とともに渦を巻〈 ${ }^{5) 。}$

ここでは、潜堤天端に用いる被覆ブロックとして砂漣形状を持つものを考え、潜堤上を入射波が進行するに したがってブロック凹部で渦が発生し、波のエネルギーを減衰させることにより、天端上水深が大きくなった 場合にも伝達率を小さくできる潜堤を開発することを目的として実験的研究を行った。

\section{2，実験装置および実験方法}

実験は、図一1に示すような、 吸収式造波装置をもつ水路長 $17.8 \mathrm{~m}$ 、水路幅 $40 \mathrm{~cm}$ 、水路高 $70 \mathrm{~cm}$ で一部両面ガラス張りの 2 次元 水槽で行った。勾配 $1 / 20$ 鋼板 製のスロープに続く高さ $30 \mathrm{~cm} の$ 水平床の上に、基礎捨石と模型 ブロックからなる潜堤を設置し た。模型縮尺は $1 / 50$ を想定し、 潜堤の高さ $10 \mathrm{~cm}$ 、天端幅は $\mathrm{B}=77 \mathrm{~cm}$ と一定とした。

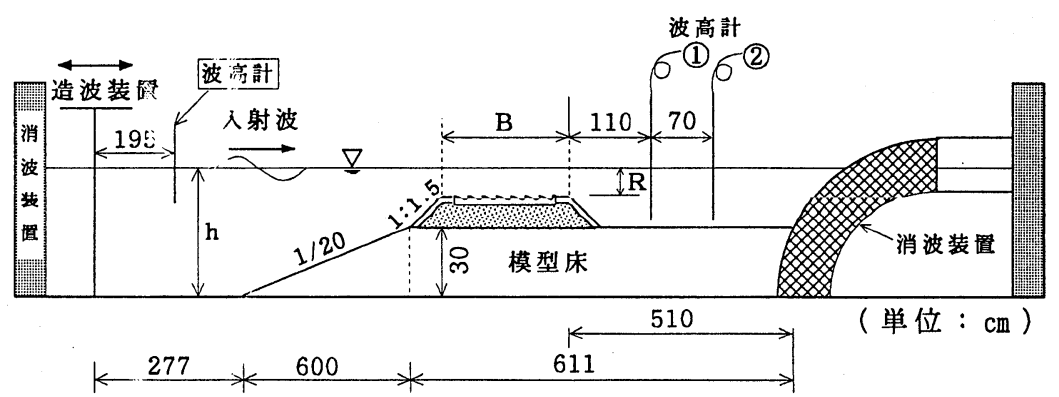

図 -1 実験装置概略

模型潜堤は合板とモルタルに より、図ー2に示すような従来型のXブロック潜堤 ${ }^{2:}$ と、今回考案の鋸刃型と波状型および他者により研究例 ${ }^{6)}$ のある垂直壁連続型を作製した。なお、すべでの実験において、法面勾配 $1: 1.5$ の部分と潜堤前後端部はXブ ロックにより被覆した。

波高測定には容量式波高計を用い、伝達波高は潜堤の天端後端より $110 \mathrm{~cm}$ と $180 \mathrm{~cm} の$ 位置で、入射波高は造波

* 正会員 九州産業大学工学部土木工学科 (813 福岡市東区松香台 $2 \cdot 丁$ 目 3 番 1 号)

** 正会員 株式会社テトラ 
板前面より $195 \mathrm{~cm}$ 位置で測定した。 入射波はすべて規則波とし、伝達波 高と入射波高の比より伝達率を求め た。

砂漣の形状は海底付近での水粒子 の運動と密接に関係することにより、 ここでは伝達率測定実験に先立ち、 砂漣形状を有するブロック模型の最 適な波長 $\lambda$ と凹部の深さ $\eta$ の概略值 を得るために、潜堤上での水粒子の 水平移動距離測定実験を行った。使 用した堤体はXブロック列であり、 沖 側

岸側
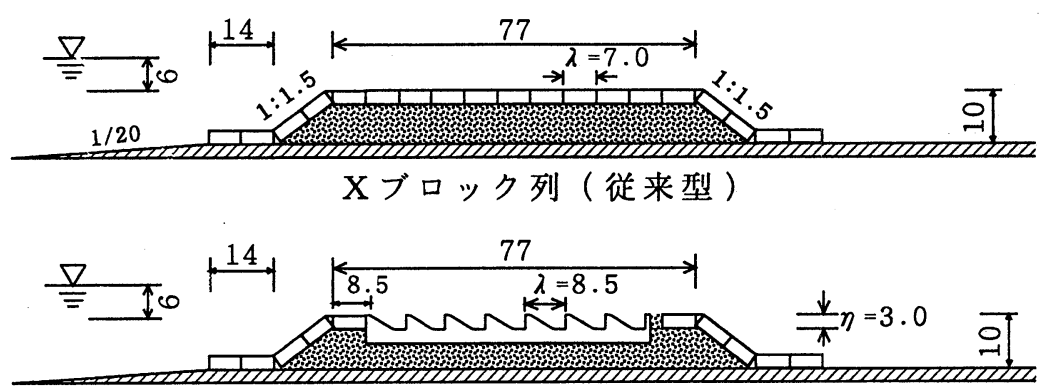

鋸刃型

実験条件は、水深 $\mathrm{h}=46 \mathrm{~cm}$ 、周期 $\mathrm{T}=0.849 ， 1.131 ， 1.414 \mathrm{sec}$ のケー ス、入射波高を $\mathrm{Hi}=4 \mathrm{~cm} \sim 14 \mathrm{~cm}$ の間 で4ケースとした。実験は $8 \mathrm{mmビデオ}$ カメラを用いることにより、天端上 での入射波の一周期あたりの水粒子 の水平距離 $\mathrm{do}(\mathrm{cm})$ を求めた。

この実験結果を基に、模型作製の 容易さを考虑して、図ー2に示すよ うな鋸刃型を基本型として、模型の 波長を $\lambda=7,8.5,10,11.5 \mathrm{~cm}$ 、凹 部の深さを $\eta=2,3,4 \mathrm{~cm}$ として製

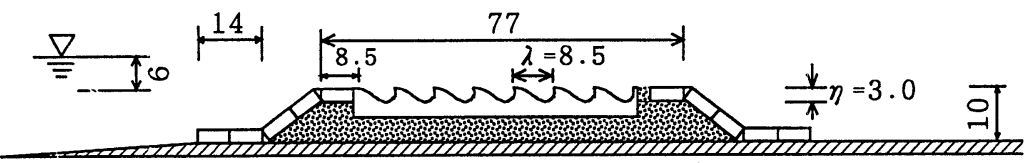

波状型

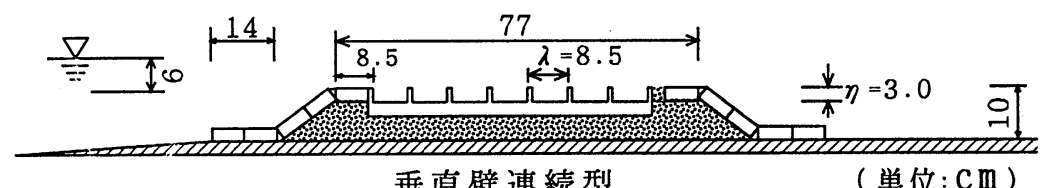

垂直壁連続型

図一 2 堤体詳細図 作した。また、模型は個々のブロッ クとせず一体構造とした。この点は実際に現地で用いる場合とは異なる。

この他、鋸刃型の実験結果を参考に模型波長 $\lambda=8.5 \mathrm{~cm}$ 、凹部の探さ $\eta=3 \mathrm{~cm}$ の波状型と垂直壁連続型の模型 を加え、全体で 10 種類の潜堤模型を製作し伝達率測定実験を行った。実験条件は、水深 $\mathrm{h}=44,46 \mathrm{~cm}$ 、周期

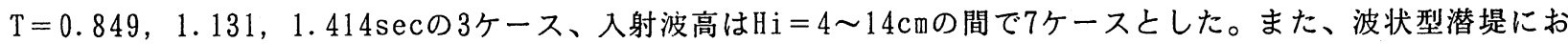
いて天端上の水面波形と水粒子の移動形態を $8 \mathrm{~mm}$ 華デオカメラを用いて測定した。

\section{3. 実験結果と考察}

図一 3 は、横軸を入射波高 $\mathrm{Hi}(\mathrm{cm})$ として水粒子の水平 移動距離 $\mathrm{do}(\mathrm{cm})$ を示す。水深は $\mathrm{h}=46 \mathrm{~cm}$ 、天端上水深は $\mathrm{R}=6 \mathrm{~cm}$ 、周期は $\mathrm{T}=0.849 ， 1.131,1.414 \mathrm{sec}$ である。

各周期について、doはHiによらずほぼ一定值となり、 ○印の周期 $\mathrm{T}=0.849 \mathrm{sec}$ ではdo $=10.3 \mathrm{~cm}$ 、 $\square$ 印の局期

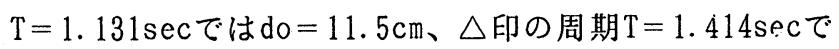
はdo=14. $7 \mathrm{~cm}$ となる。すなわち、周期が長くなるに従っ てdoは、大きくなっている。

図一4は、横軸を入射波高Hi $(\mathrm{cm})$ として鋸刃型堤体の 伝達率 $\mathrm{Kt}$ を示している。水深 $\mathrm{h}=46 \mathrm{~cm}$, 天端上水深 $\mathrm{R}=6 \mathrm{~cm}$, 周期 $\mathrm{T}=1.131 \mathrm{~s} \mathrm{ec}$, 模型波長 $\lambda=8.5 \mathrm{~cm}$ にお いて、模型凹部の深さを $\eta=2,3 ， 4 \mathrm{~cm}$ とした。伝達率 $\mathrm{Kt}$ は、入射波高が大きくなるに従って小さくなってい

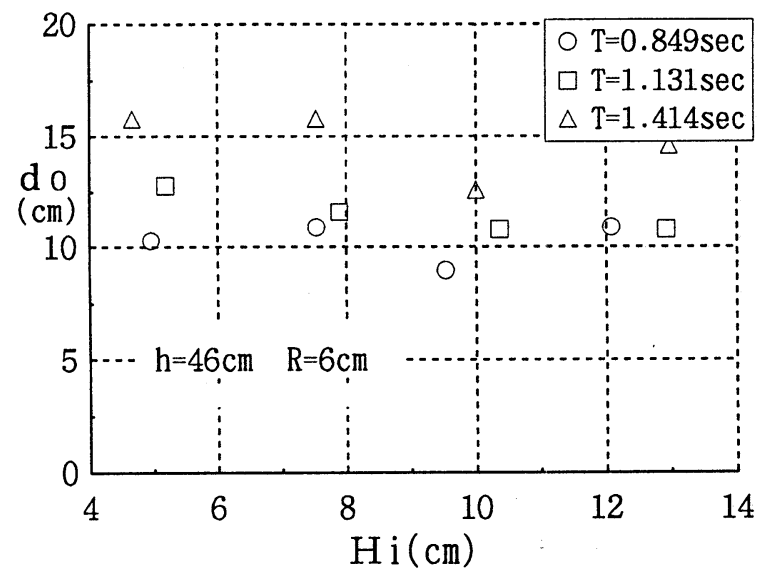

図-3 天端上の水粒子の水平移動距離

るが、入射波高がH $\mathrm{i}=5 \mathrm{~cm}$ を除いて、 $\triangle$ 印の $\eta_{1}=3 \mathrm{~cm}$ の

$\mathrm{K}$ tが他と比べて小さくなっている。 $\eta=4 \mathrm{~cm}$ では深すぎるため渦が発生しにくく、 $\eta=2 \mathrm{~cm}$ は、渦は発生する が、渦の大きさよりも凹部が小さく伝達率が小さくなっている。

図一 5 は、水深 $\mathrm{h}=46 \mathrm{~cm}$ 、天端上水深 $\mathrm{R}=6 \mathrm{~cm}$ 、周期 $\mathrm{T}=1.414 \mathrm{sec}$ における模型凹部の深さ $\eta=3 \mathrm{~cm}$ 、模型波長 


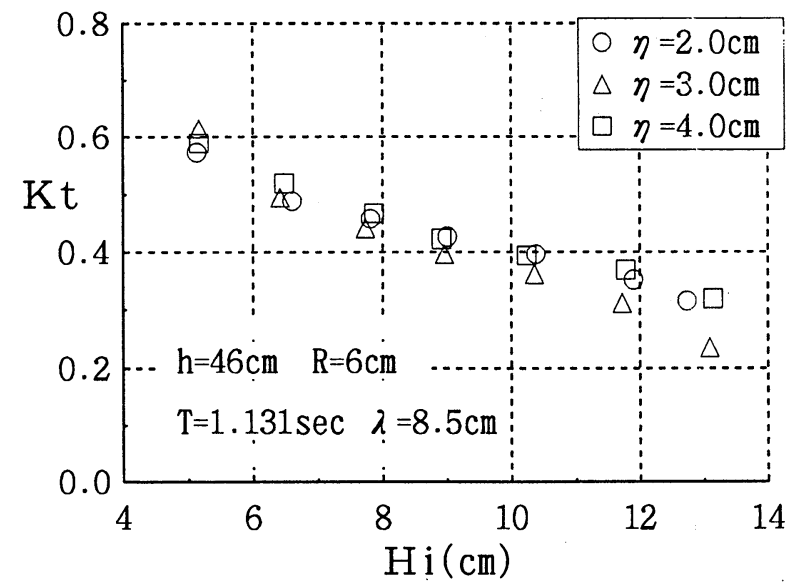

図ー4クを変化させたときのKtの比較（鋸刃型）

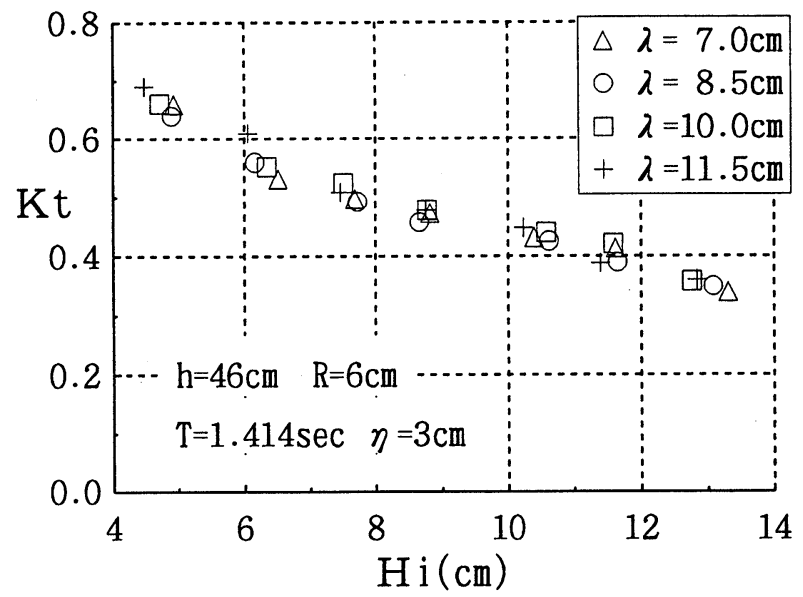

図一 5 入を変化させたときのKtの比較（鋸刃型）

$\lambda$ を7，8.5，10，11.5 cmと変化したときの $\mathrm{K} t$ を示す。すべての $\lambda に$ 対して、入射波の波長が長く、水粒子の移 動距離doに対応していないため、K tはほぼ同程度の值を示している。

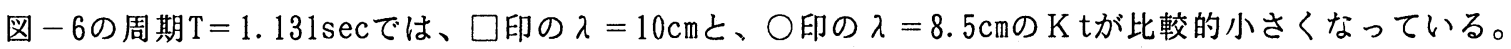

図 -7 の周期 $\mathrm{T}=0.849 \mathrm{sec}$ では、この傾向が強く現れ、特に入射波高 $10 \mathrm{~cm}$ 以上では、 $\lambda=8.5 \mathrm{~cm}$ の伝達率が小さ くなっている。このように、入射波の条件と、模型形状を対応させれば、天端上水深が深いのにもかかわらず 伝達率は小さくなる傾向にある。

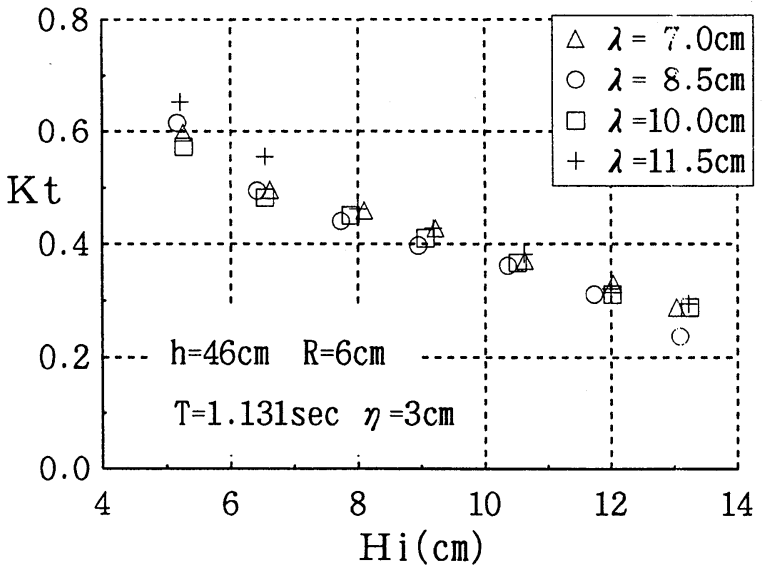

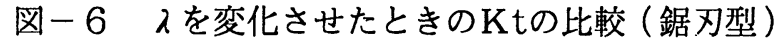

図一8は、水深 $\mathrm{h}=46 \mathrm{~cm}$ 、天端上水深 $\mathrm{R}=6 \mathrm{~cm}$, 周期 $\mathrm{T}=1.414 \mathrm{sec} に お け る$ 模型凹部の深さ $\eta=3 \mathrm{~cm}$ 時の模型 形状の違いによるK tを比較したものである。・印はXブ ロック列、メ印は垂直壁連続型、○印は鋸刃型、 $\triangle$ 印は 波状型である。 $\mathrm{Hi}=8 \mathrm{~cm}$ 付近で、この 4 堤体の $\mathrm{Kt}$ tは活ぼ 同様の傾向を示すが、入射波高が $10 \mathrm{~cm}$ 以上になると锯刃 型と波状型の $\mathrm{K}$ 切小さくなっている。

図-9，10は、同様に周期 $\mathrm{T}=1.131$ と $0.849 \mathrm{sec}$ 模型形 状の違いによる K tの比較を示す。鋸刃型と波状型の K t は入射波高にかかわらず、従来型のXブロック列のそれ よりも小さくなる。特に、入射波高が大きいほどこの傾 向が強く現れる。

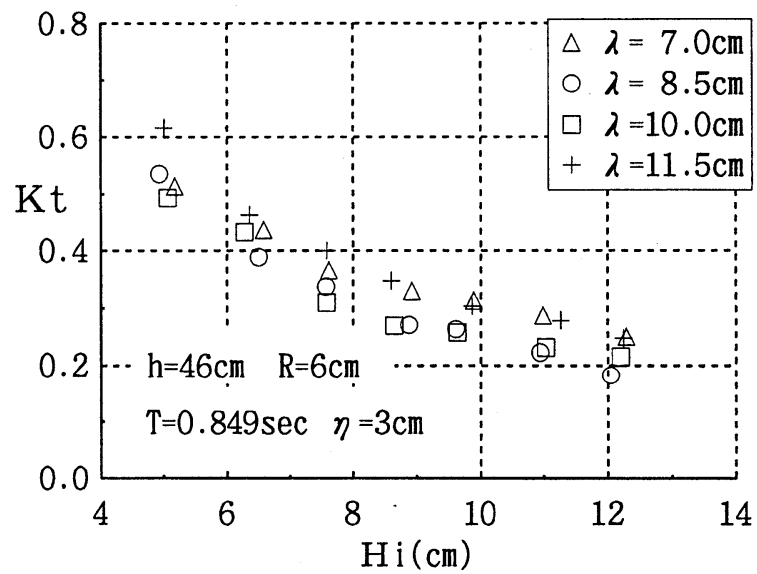

図ー7 入を変化させたときの Ktの比較（鋸刃型）

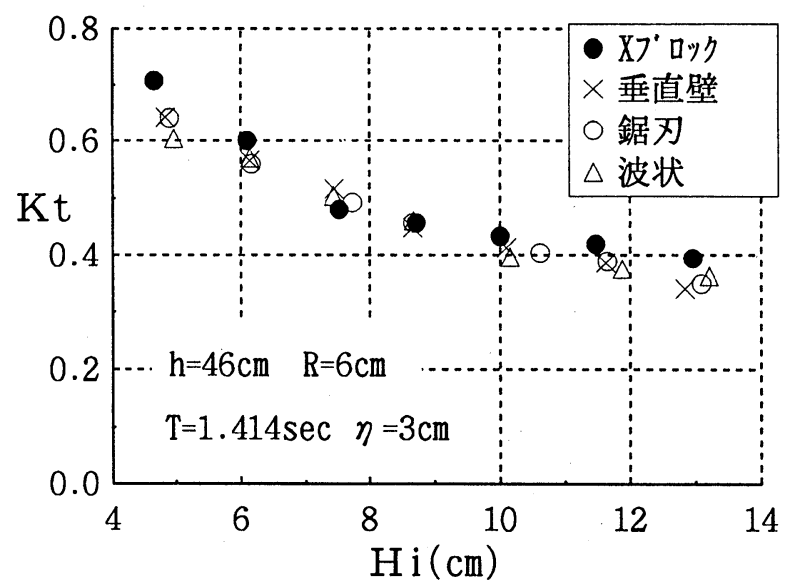

図-8 模型形状を変化させたときのKtの比較 


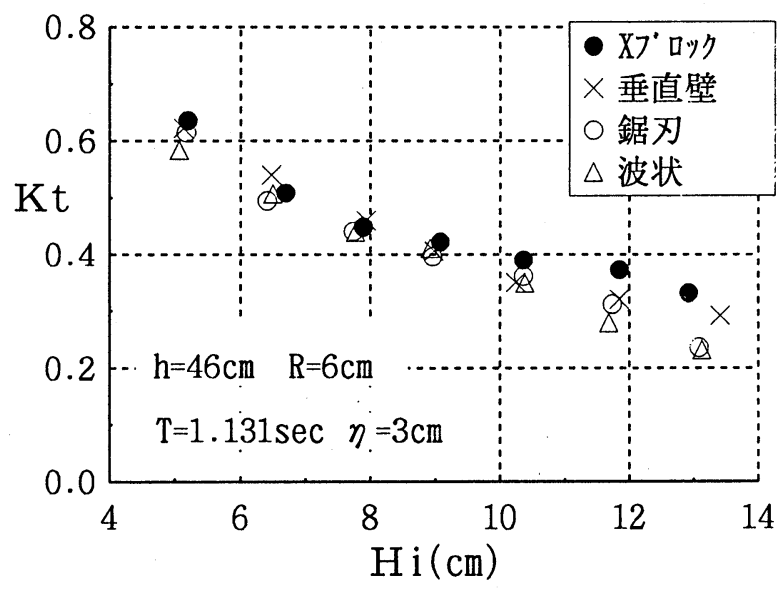

図ー9 模型形状を変化させたときのKtの比較

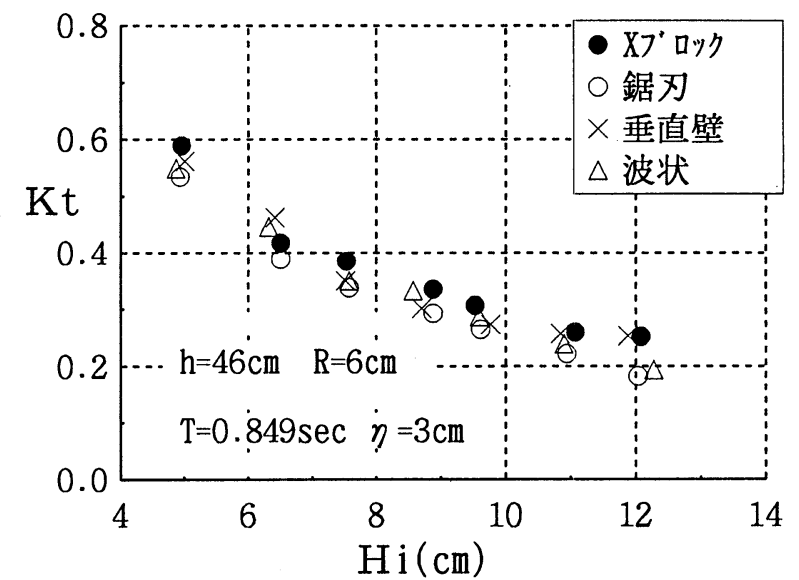

図ー10 模型形状を変化させたときのKtの比較

図一 11 は、水深が $\mathrm{h}=44 \mathrm{~cm}$ で、天端上水深を $\mathrm{R}=4 \mathrm{~cm}$ と 浅くしたときの、Xブロック列と波状型（ $\lambda=8.5 \mathrm{~cm}$ 、 $\eta=3 \mathrm{~cm})$ の $\mathrm{K}$ tを示す。

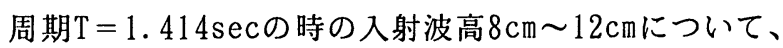
伝達率は波状型の方が小さいものの、 $\mathrm{T}=1.131 \mathrm{sec} の$ 時 を含めて全体的には両者の伝達率はほとんど変わらな い。前述の天端上水深が $\mathrm{R}=6 \mathrm{~cm}$ の場合とは傾向が異な り、興味深い。この点については、更に実験を重ね検 討する必要がある。

\section{4. 水面波形と水粒子の移動}

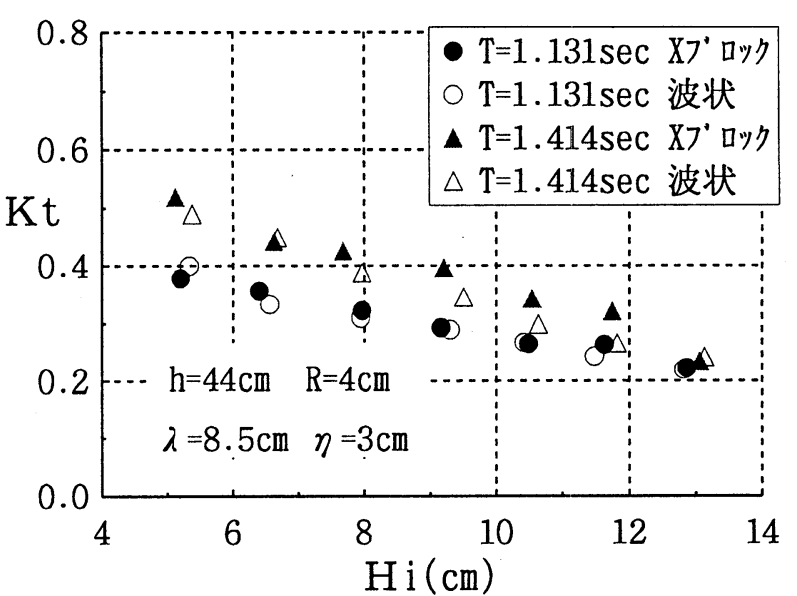

図-11 周期,模型形状の変化によるKtの比較

波状型堤体（ $\lambda=8.5 \mathrm{~cm} 、 \eta=3 \mathrm{~cm} ）$ における水面波形と水粒子の移動について一周期あたりの波の山と谷が 潜堤上を通過するときの 2 つに分け、模型凹部近傍で渦がどのように発生し、波のエネルギーが減衰するかを 実験により調べた。実験条件は、水深 $\mathrm{h}=46 \mathrm{~cm} 、$ 天端上水深 $\mathrm{R}=6 \mathrm{~cm}$ 、周期 $\mathrm{T}=1.131 \mathrm{sec}$ 、入射波高 $\mathrm{H} \mathrm{i}=5.1 \mathrm{~cm}$ と した。

測定は、造波開始後、 4 波目から安定した波の入射時に比重0.93のペイント吹き付けのプラスチック粒子を

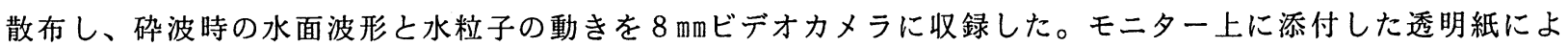
り求めた水粒子の移動は、砕波地点の前後にあたる潜堤沖側端から 3 番目から 6 番目までの波状凹部とし、こ こでは 5 番目の部分について示す。波の動きは、ビテオにより 1 周期あたり 33 コマ ( 1 秒間に30コマ) の波形 が記録できるため、水面波形は凹部 3 番目を波の山が通過する時を 1 として、1 29までを 4 つおきに 8 個示 した。

図一12に示すように、波の山が潜堤上を通過するとき、波状型是体の凹部で時計回りの渦が発生しているこ とが分かる。また、図ー13に示すように波の谷の時は、天端上の水粒子は全体的に沖向きであるため、凹部で は反時計回りの渦が発生している。このように、波の山と谷が通過するときに、四部で相反する向きを持つ渦 が発生することにより、波のエネルギーが減衰し、伝達率が低下すると考えられる。 


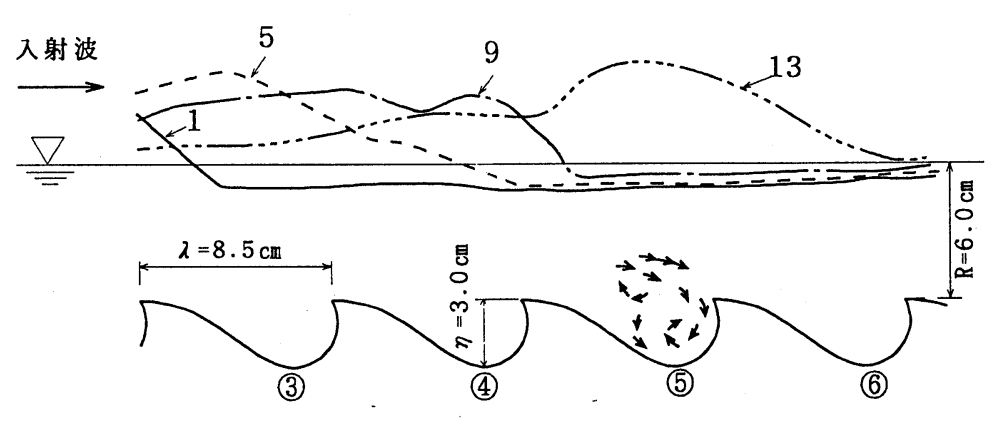

$\mathrm{h}=46 \mathrm{~cm}, \mathrm{R}=6 \mathrm{~cm}, \mathrm{~T}=1.131 \mathrm{sec}, \mathrm{Hi}=5.1 \mathrm{~cm}$

図一 12 波の山が(5)通過するときの水面波形と水粒子の動き

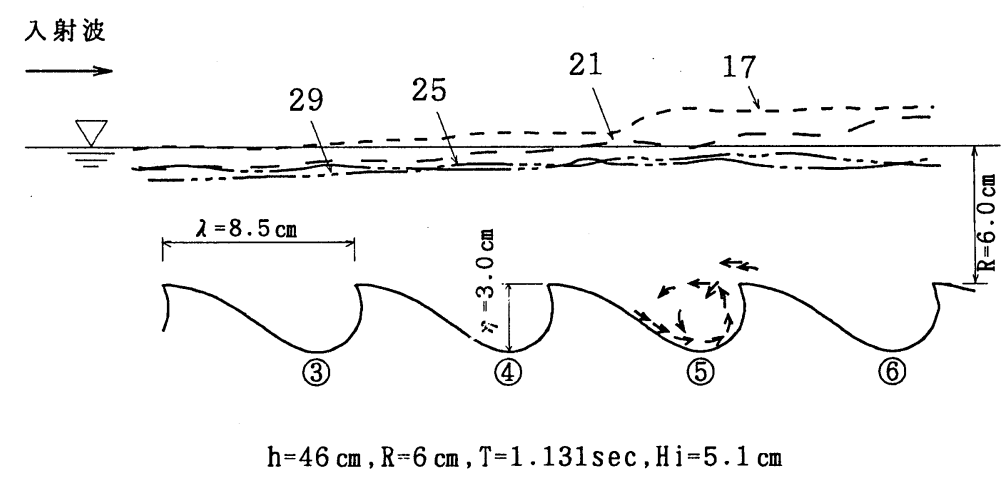

図一 13 波の谷が(5)を通過するときの水面波形と水粒子の動き

\section{5.むすび}

今回の実験条件である、海底勾配 $1 / 20$ の海域に設置された、潜堤高さ $5 \mathrm{~m} （$ 縮尺を $1 / 50$ と想定しているので、 現地寸法で示す。以下同じ。）、天端幅 $40 \mathrm{~m}$ 、天端上水深 $3 \mathrm{~m}$ の潜堤において、周期 $\mathrm{T}=6 \sim 10$ 秒、入射波高 $\mathrm{Hi}=2 \sim 7 \mathrm{~m}$ の波に対して、ブロック波長 $\lambda=4 \mathrm{~m}$ 、ブロック凹部の深さ $\eta=1.5 \mathrm{~m}$ 程度の波状型または鋸刃型の被 覆ブロック列（ここでは岸沖方向に 7 列）を用いれば、従来型の潜堤と比較して、伝達率を小さくできる。 波状型被覆ブロック潜堤の伝達率が低下する理由としては、潜堤天端上を波の山と谷が通過する時、ブロッ ク凹部で相反する向きをもつ渦の発生により波エネルギーの隇衰が行われる為と考えられる。

今後は、入射波の条件と最適ブロック寸法の関係を更に明らかにする必要がある。

\section{参考文献}

1）（社）全国海岸協会：人エリーフの設計の手引き、pp. 1 94、1992.

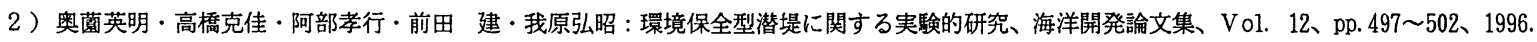

3) 田中則男：天端幅の広い潜堤の波浪減殺および砂浜安定効果について、第23回海岸工学講演会論文集、pp. 152 157、1976.

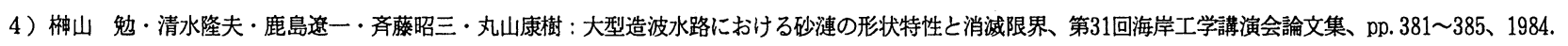

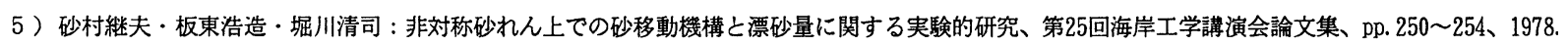

6 ）清川哲志：斜波中の䙡数鉛直板型潜提の透過性、海岸工学論文集、第 37 巻、pp. 579 583、1990. 